\title{
Analisis Kemampuan Pemecahan Masalah Matematis pada Materi Kubus dan Balok di SMP
}

\author{
Hermawati $^{*}$, Jumroh ${ }^{2}$, dan Eka Fitri Puspa Sari ${ }^{3}$ \\ 1*2,3Pendidikan Matematika, Universitas PGRI Palembang \\ Jalan Jend. Ahmad Yani Lr. Gotong Royong Palembang \\ 1*Mawatiher@gmail.com; 2 Jumrohdahlan@gmail.com; 3 ekafitrips@univpgri_palembang.ac.id
}

Artikel diterima: 19-10-2020, direvisi: 29-01-2021, diterbitkan: 31-01-2021

\begin{abstract}
Abstrak
Kemampuan pemecahan masalah tidak lepas dari kegiatan belajar mengajar pada umumnya karena keberhasilan seseorang terhadap sesuatu yang dihadapi tidak lepas dari matematika. Penelitian ini bertujuan untuk mengetahui kemampuan pemecahan masalah matematis peserta didik kelas IX di SMP Negeri 15 Palembang. Sampel pada penelitian ini di ambil secara acak yaitu peserta didik kelas IX.1 berjumlah 31 peserta didik yang dilakukan di SMP Negeri 15 Palembang tahun Pelajaran 2019/2020. Teknik pengumpulan data menggunakan soal tes berbentuk uraian materi bangun ruang (kubus dan balok). Teknik analisis data dalam penelitian ini adalah deskriptif kuantitatif. Dari hasil analisis data dan pembahasan maka dapat disimpulkan bahwa kemampuan pemecahan masalah matematis peserta didik dikategorikan rendah.

Kata Kunci: Kemampuan Pemecahan Masalah. Penelitian Deskriptif Kuantitatif, Materi Bangun Ruang.
\end{abstract}

Analysis of Mathematical Problem-Solving Ability on Cubes and Blocks in Junior High School

\begin{abstract}
The ability to solve problems cannot be separated from teaching and learning activities in general because one's success in something that is faced cannot be separated from mathematics. This Study aims to determine the mathematical Problem-solving abilities of grade IX students at SMP Negeri 15 Palembang. The sample in this study was taken randomly. namely students of class IX.1, totaling 31 students which was conducted at SMP Negeri 15 Palembang for the 2019/2020 academic year. The data collection technique used test questions in the form of a description of the material (cubes and cuboid). The data analysis technique in this research is descriptive quantitative. From the results of data analysis and discussion, it can be concluded that the students mathematical Problem-solving ability is categorized as low.

Keywords: problem solving abilities, descriptive quantitative, material (cubes and cuboid).
\end{abstract}




\section{Pendahuluan}

Kemajuan suatu negara tidak lepas dari faktor pedidikan (Arimurti, Praja, \& Muhtarulloh, 2019), dimana pendidikan selalu di pandang untuk memajukan sesorang agar dapat lebih mengembangkan pengetahuan yang dimiliki dan penting untuk memperluaskan kemampuan seseorang dalam memahami dirinya sendiri (Rahman \& Nasryah, 2020). Danim (2017:2) berpendapat bahwa melalui kemampuan pengetahuan, keterampilan dan sikap mampu membuat seseorang menuju tingkatan yang lebih tinggi.

Pendidikan matematika memegang peranan yang sangat penting dalam meningkatkan mutu manusia (Herawati \& Nurhayati, 2019). Matematika menjadi salah satu mata pelajaran yang seharusnya mampu dipahami dengan lebih baik, namun mata pelajaran matematika secara garis besar masih dianggap sulit dan juga menakutkan oleh beberapa peserta didik (Afriansyah, 2014; Febrilia, 2019; Lisnani, 2019). Menurut Hamzah \& Muhlisrarini (2014:57) pendidikan matematika adalah salah satu proses untuk meningkatkan kemampuan nalar peserta didik, meningkatkan kecerdasan peserta didik, dan mengubah sikap positifnya. Berdasarkan wawancara dengan salah satu guru matematika di SMP Negeri 15 Palembang pendidikan matematika menjadi mata pelajaran yang begitu sulit bagi peserta didik untuk saat ini bahkan ada yang beranggapan bahwa matematika menjadi salah satu pelajaran yang menakutkan untuk dihadapi. Dari hal ini peserta didik mengalami kesulitan untuk menyelesaikan soal yang ditugaskan untuk mencari pemecahan persoalan matematika yang diberikan.

Kemampuan pemecahan masalah tidak lepas dari kegiatan belajar mengajar pada umumnya karena keberhasilan seseorang terhadap sesuatu yang dihadapi tidak lepas dari matematika (Sopian \& Afriansyah, 2017; Latifah \& Luritawaty, 2020). Menurut Sumartini (2016:149) peserta didik masih relatif kurang dalam menyelesaikan kemampuan pemecahan masalah. Permasalahan ini biasanya disebabkan oleh beberapa hal seperti kurangnya berminat belajar matematika pada peserta didik (Firnanda \& Pratama, 2020), hal ini dikarenakan dalam memberi informasi mengenai materi matematika masih terfokus kepada guru dalam proses pembelajaran (Afriansyah, dkk., 2020).

Menurut Mairing (2018:64) pemecahan masalah merupakan permasalahan yang diarahkan untuk mendapatkan suatu jawaban dengan cara berpikir. Peserta didik mampu untuk memecahkan masalah matematis jika mereka mampu memahami (Cahirati, Makur, \& Fedi, 2020), menentukan strategi yang benar (Nurmawanti \& Sulandra, 2020), dan kemudian menerapkannya dalam penyelesaian masalah (Rokhima \& Fitriyani, 2018).

Kemampuan pemecahan masalah matematis yang baik akan berpengaruh 
terhadap hasil belajar matematika supaya menjadikannya lebih baik serta dapat menjadi tujuan umum dalam pembelajaran matematika, karena kemampuan pemecahan masalah matematis dapat membantu dalam memecahkan persoalan baik dalam pembelajaran lain maupun dalam kehidupan sehari-hari (Albab, Saputro, \& Nursyahidah, 2017; Rinaldi \& Afriansyah, 2019). Menurut Yarmayani (2016:13) kurangnya kemampuan pemecahan masalah matematis peserta didik juga dapat menyebabkan proses belajar mengajar matematika itu tidak mencapai tujuan hasil belajar yang diharapkan.

Dalam proses pembelajaran guru masih dominan dalam menyampaikan materi langsung dari buku (Afriansyah, 2013; Zakiyah, Hidayat, \& Setiawan, 2019). Kubus dan Balok menjadi salah satu materi yang tidak lepas dari permasalahan matematika yang berkaitan dengan kehidupan sehari-hari salah satu contohnya mengetahui luas sebuah meja belajar dan luas bangunan yang ada dalam ruang kelas (Widiawati \& Sofyan, 2013; Sitohang, 2020). Banyak guru yang sering memberikan contoh soal yang mirip dengan contoh yang ada di buku (Sumartini, dkk., 2020). Sehingga dapat menyebabkan peserta didik masih bingung ketika dihadapkan dengan soal yang sedikit berbeda dari contoh yang diajarkan, maka peserta didik langsung kebingungan dan masih terlihat sulit untuk mengerjakan soal dan memecahkan masalah yang diberikan.

Berdasarkan fakta tersebut, maka penulis terinspirasi untuk melakukan penelitian yang bertujuan untuk menganalisis kemampuan pemecahan masalah matematis peserta didik.

\section{Metode}

Jenis penelitian ini menggunakan deskriptif kuantitatif. Populasi penelitian adalah peserta didik kelas IX SMP Negeri 15 Palembang. Sedangkan sampel penelitian adalah peserta didik kelas IX.1 yang diambil secara acak. Peneliti menyusun instrumen tes dengan menggunakan soal tes sebanyak 3 butir. Tes berbentuk soal uraian atau essay yang mengacu kepada indikator kemampuan pemecahan masalah peserta didik yaitu menentukan permasalahan masalah, mampu membuat permodelan matematika, mampu mengembangkan cara pemecahan serta menjelaskan jawaban yang diperoleh dari penyelesaian masalah. Kemudian hasil tes yang dikumpulkan dalam penelitian ini digunakan untuk mengetahui kemampuan peserta didik dalam pemecahan masalah peserta didik, karena data yang diperoleh akan dijadikan landasan untuk pengambilan kesimpulan. Untuk mendapat hasil dari kemampuan pemecahan masalah matematis maka dilakukanlah penskoran pada setiap jawaban peserta didik dalam tiap butir soal. 
Adapun analisis data dalam penelitian ini adalah sebagai berikut. Validitas merupakan derajat ketepatan antara data yang terjadi pada obyek penelitian dengan daya yang dapat dilaporkan oleh peneliti (Sugiyono, 2018:363). Adapun rumus yang digunakan.

$$
=\frac{r_{x y}}{\sqrt{\left\{\mathrm{N} \sum \mathrm{X}^{2}-\left(\sum \mathrm{X}-\left(\sum\right)^{2}\right\} \cdot\{\mathrm{X}) \cdot\left(\sum \mathrm{Y}\right)\right.}}
$$

Keterangan :

$r_{x y}=$ Koefisien korelasi antara skor butir soal (X) dan total skor ( $\mathrm{Y}$ )

$\mathrm{N}=$ Banyak subjek

$\mathrm{Y}=$ total skor

$X \quad=$ Jumlah skor butir soal atau skor item pertanyaan

Kriteria pengujian suatu instrumen dikatakan signifikan atau valid jika diperoleh koefisien korelasinya $r_{x y}>$ $r_{\text {tabel }}$, dan dengan taraf signifikan $(\alpha=$ 0,05).

Reliabilitas adalah salah satu instrumen yang dapat dikuatkan untuk dijadikan sebagai alat mengumpul data karena instrumen tersebut sudah dapat digunakan (Arikunto, 2014:221). Adapun rumus yang digunakan.

$$
r_{11}=\left(\frac{\mathrm{k}}{\mathrm{k}-1}\right)\left(1 b-\frac{\sum \sigma_{\mathrm{b}}{ }^{2}}{\sigma_{t}{ }^{2}}\right)
$$

Keterangan :

$r_{11}=$ reliabilitas instrumen

$\mathrm{k}$ = banyaknya butir pertanyaan atau banyaknya soal

$\sum{\sigma_{\mathrm{b}}}^{2}=$ jumlah varians butir $\sigma_{t}^{2}=$ varians total

Kriteria pengujian reliabilitas yaitu apabila $r_{11 \text { hitung }}>r_{\text {tabel }}$

Daya pembeda dari satu butir soal digunakan untuk menyatakan seberapa luasnya kemampuan butir soal tersebut. Rumus yang digunakan.

$$
D_{p}=\frac{\bar{X}_{A}-\bar{X}_{B}}{S M I}
$$

Sumber (Lestari\&Yudhanegara, 2015:217)

Keterangan:

$D_{p}=$ Daya pembeda

$\bar{X}_{A} \quad=$ Rata-rata skor jawaban peserta didik kelompok atas

$\bar{X}_{B} \quad=$ Rata-rata skor jawaban peserta didik kelompok bawah

SMI = Skor maksimum ideal, yaitu skor maksimum yang akan diperoleh peserta didik menjawab soal tersebut dengan tepat.

Tabel 1

Kriteria Daya Pembeda Instrumen

\begin{tabular}{|ll|}
\hline Nilai & Interpretasi daya pembeda \\
\hline $0,70<D P \leq 1,00$ & Sangat baik \\
\hline $0,40<D P \leq 0,70$ & Baik \\
\hline $0,20<D P \leq 0,40$ & Cukup \\
\hline $0,00<D P \leq 0,20$ & Buruk \\
\hline$D P \leq 0,00$ & Sangat buruk \\
& (Lestari \& Yudhanegara, 2015:217)
\end{tabular}

Lestari \& Yudhanegara (2018:223) indeks kesukaran adalah suatu bilangan yang menyatakan derajat kesukaran atau mudahnya suatu butir soal.

$$
I K=\frac{\bar{X}}{S M I}
$$

(Lestari \& Yudhanegara, 2015:224)

Keterangan:

$\mathrm{IK}=$ Indeks kesukaran 
$\bar{X} \quad=$ Rata-rata skor jawaban peserta didik pada soal

$S M I=$ Skor maksimum Ideal, yaitu skor maksimum yang akan diperoleh peserta didik menjawab soal tersebut dengan tepat.

Tabel 2

Kriteria Indeks Kesukaran Instrumen

\begin{tabular}{ll|}
\hline IK & $\begin{array}{l}\text { Interpretasi } \\
\text { kesukaran }\end{array}$ \\
\hline $\mathrm{IK}=0,00$ & Terlalu sukar \\
\hline $0,00<\mathrm{IK} \leq 0,30$ & Sukar \\
\hline $0,30<\mathrm{IK} \leq 0,70$ & Sedang \\
\hline $0,70<\mathrm{IK} \leq 1,00$ & Mudah \\
\hline $\mathrm{I}=1,00$ & Terlalu Mudah \\
\hline & (Lestari \& Yudhanegara, 2015:224) \\
\hline
\end{tabular}

Nilai yang diperoleh selanjutnya dikategorikan menurut tingkat kemampuan pemecahan masalah peserta didik. Pada penelitian ini, tingkat kemampuan pemecahan masalah peserta didik ditetapkan sebagai berikut.

Tabel 3

Kategori Kemampuan Pemecahan Masalah Matematis

\begin{tabular}{cc|}
\hline Persentase pencapaian & Kategori \\
\hline $75<\mathrm{P} \leq 100$ & Tinggi \\
\hline $60<\mathrm{P} \leq 75$ & Sedang \\
\hline $0<\mathrm{P} \leq 60$ & Rendah \\
\hline
\end{tabular}

Persentase kemapuan pemecahan masalah peserta didik dalam setiap kategori ditentukan menggunakan rumus berikut ini.

$$
P=\frac{\sum \text { skor yang diperoleh setiap pertanyaan }}{\text { skor maksimal }} \times 100 \%
$$

\section{Hasil dan Pembahasan}

Penelitian ini dilakukan terhadap 31 peserta didik kelas IX.1 SMP Negeri 15 Palembang. Tes yang diberikan berupa soal esai dengan materi bangun ruang(kubus dan balok). Soal yang digunakan dalam penelitian ini berjumlah 3 soal dengan waktu yang diberikan 2 jam pelajaran. Bentuk soal dapat dilihat pada Gambar 1 berikut ini.

Sebuah kardus berbentuk balok dengan ukuran panjang $48 \mathrm{~cm}$, lebar $30 \mathrm{~cm}$ dan tinggi 16 $\mathrm{cm}$. jika diketahui suatu kotak kapur berbentuk kubus dengan panjang rusuknya $8 \mathrm{~cm}$. Berapa banyak kotak kapur yang dibutuhkan untuk mengisi kardus tersebut?

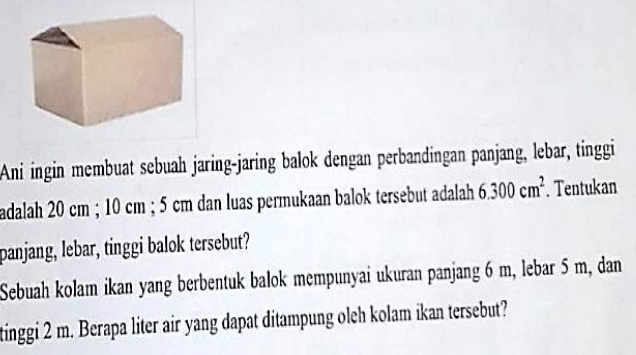

Gambar 1. Bentuk Soal yang Diberikan.

Sesuai dengan metode penelitian, kemampuan pemecahan masalah matematis peserta didik dibagi kedalam tiga tingkatan yaitu tinggi, sedang, dan rendah berdasarkan pencapaian nilai peserta didik yang diperoleh, kategori tingkatan kemampuan pemecahan masalah matematis dapat dilihat pada Tabel 3. 
Data keseluruhan dapat dilihat pada Tabel 4 berikut ini.

Tabel 4

Hasil Kriteria Kemampuan Pemecahan Masalah

\begin{tabular}{|c|c|c|c|}
\hline No & $\begin{array}{c}\text { Kategori Kemampuan } \\
\text { Pemecahan Masalah } \\
\text { Matematis }\end{array}$ & $\begin{array}{c}\text { Banyaknya } \\
\text { Peserta Didik } \\
\text { (Orang) }\end{array}$ & Persentase \\
\hline 1 & Tinggi & 4 & $12,90 \%$ \\
\hline 2 & Sedang & 8 & $25,81 \%$ \\
\hline 3 & Rendah & 19 & $61.29 \%$ \\
\hline & Jumlah & 31 & $100 \%$ \\
\hline
\end{tabular}

Diketahui bahwa tabel 4 berupa nilai hasil keseluruhan jawaban yang didapatkan 31 peserta didik yang dikelompokkan berdasarkan nilai keseluruhan yang diperoleh dari seluruh indikator. Dimana terdapat 4 peserta didik yang dikategorikan tinggi dalam menyelesaikan soal kemampuan pemecahan masalah matematis, 8 peserta didik yang dikategorikan sedang dalam menyelesaikan soal kemampuan pemecahan masalah matematis, dan 19 peserta didik dikategorikan rendah dalam menyelesaikan soal kemampuan pemecahan masalah matematis. Selanjutnya dihitung hasil jawaban tes peserta dilihat keempat indikator kemapuan pemecahan masalah matematis peserta didik.
Tabel 5

Kemampuan Pemecahan Masalah

\begin{tabular}{|l|c|c|}
\hline \multicolumn{1}{|c|}{$\begin{array}{c}\text { Indikator pemecahan } \\
\text { masalah }\end{array}$} & $\begin{array}{c}\text { Persentase jawaban } \\
\text { peserta didik (\%) }\end{array}$ & Kategori \\
\hline $\begin{array}{l}\text { Menunjukan permasalahan } \\
\text { masalah }\end{array}$ & 38,35 & Rendah \\
\hline $\begin{array}{l}\text { Membuat/menyusun } \\
\text { model matematika }\end{array}$ & 65,23 & Sedang \\
\hline $\begin{array}{l}\text { Memilih dan } \\
\text { mengembangkan strategi } \\
\text { pemecahan }\end{array}$ & 73,48 & Sedang \\
\hline $\begin{array}{l}\text { Menjelaskanjawabanyang } \\
\text { diperoleh dar } \\
\text { penyelesaianmasalah. }\end{array}$ & 31,54 & Rendah \\
\hline
\end{tabular}

Tabel 5 menunjukkan hasil sesuai indikator dari seluruh peserta didik, dimana terdapat 38,35\% peserta didik mengalami kesalahan dalam menunjukkan permasalah masalah dikategorikan rendah, sebesar 65,23 peserta didik sudah mampu membuat/menyusun model matematika pada soal dikategorikan sedang, sebesar 73,48 peserta didik mampu memilih dan mengembangkan strategi pemecahan dikategorikan sedang, dan sebesar 31,54 peserta didik kurang mampu dalam menjelaskan jawaban yang diperoleh dari penyelesaian masalah. Persentase rata- rata keterampilan kemampuan pemecahan masalah matematis peserta didik yang ditunjukkan pada tabel 5 menunjukkan 41,72 berdasarkan pengkategori kemampuan pemecahan masalah matematis berdasarkan tabel 3, maka dikategorikan rendah.

Hasil penelitian menunjukkan berbagai kesalahan-kesalahan jawaban peserta didik dalam menyelesaikan soal bangun 
ruang (kubus dan balok) dilihat pada analisis berikut ini.

\section{A. Kemampuan Pemecahan Masalah Matematis Tinggi (T)}

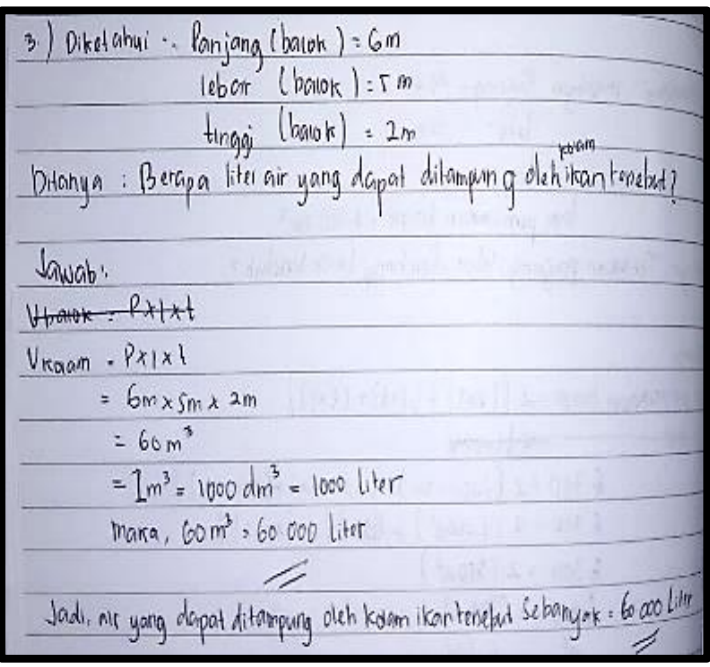

Gambar 2. Peserta Didik dengan Kemampuan Pemecahan Masalah Tinggi.

Peserta didik dengan kemampuan pemecahan masalah matematis tinggi, pada indikator pertama yaitu menunjukan permasalahan masalah, salah satu peserta didik pada kategori (T) yaitu UR dapat memahami kondisi atau masalah yang ada pada soal dan dapat memberikan informasi yang diketahui dan ditanyakan pada soal tersebut dikategorikan rendah, sesuai dengan apa yang telah dituliskan peserta didik di lembar jawabannya (lihat Gambar 2). Pada indikator kedua yaitu membuat/menyusun model matematika, UR dapat membuat suatu hubungan dari data yang diketahui dan tidak diketahui, sesuai dengan apa yang telah dituliskan peserta didik di lembar jawabannya. Pada indikator ketiga yaitu memilih dan mengembangkan strategi pemecahan, UR didik dapat memilih dan mengembangkan strategi untuk melakukan perhitungan dengan segala macam yang dibutuhkan seperti konsep dan rumus yang sesuai, sesuai dengan apa yang telah dituliskan peserta didik di lembar jawabannya. Dan pada indikator keempat yaitu menjelaskan jawaban yang diperoleh dari penyelesaian masalah, UR dapat berusaha untuk menjelaskan kembali jawaban dengan teliti setiap tahap yang dilakukan, sesuai dengan apa yang telah dituliskan peserta didik di lembar jawabannya.

\section{B. Kemampuan Pemecahan Masalah Matematis Sedang (S)}

$\begin{aligned} & \text { 3. Dik: } P=6 \mathrm{~m} \\ & 1=5 \mathrm{~m} \\ & t=2 \mathrm{~m} \\ & \text { Dit: bep liter air yg dpt ditampung dim koiam? } \\ & \text { Jwb: } \\ & V=P \times 1 \times t \\ &: 6 \times 5 \times 2 \\ &=60 \mathrm{~cm}^{3}\end{aligned}$

Gambar 3. Peserta Didik dengan Kemampuan Pemecahan Masalah Sedang.

Peserta didik dengan kemampuan pemecahan masalah matematis sedang, pada indikator pertama yaitu menunjukan permasalahan masalah, salah satu peserta didik pada kategori (S) yaitu $\mathrm{AH}$ dapat memahami kondisi atau masalah yang ada pada soal dan dapat memberikan informasi yang diketahui dan ditanyakan pada soal tersebut, sesuai dengan apa yang telah dituliskan peserta didik di 
lembar jawabannya (lihat Gambar 3). Pada

indikator kedua yaitu membuat/menyusun model matematika, AH dapat membuat suatu hubungan dari data yang diketahui dan tidak diketahui, sesuai dengan apa yang telah dituliskan peserta didik di lembar jawabannya. Pada indikator ketiga yaitu memilih dan mengembangkan strategi pemecahan peserta didik dapat memilih dan mengembangkan strategi untuk melakukan perhitungan dengan segala macam yang dibutuhkan seperti konsep dan rumus yang sesuai, pada indikator ke tiga ini $\mathrm{AH}$ kurang lengkap dalam mengerjakan soal. Dan pada indikator keempat yaitu menjelaskan jawaban yang diperoleh dari penyelesaian masalah, peserta didik dapat berusaha untuk menjelaskan kembali jawaban dengan teliti setiap tahap yang dilakukan, pada indikator keempat peserta didik tidak menjelaskan kembali jawaban yang diperoleh sebelumnya jadi pada jawaban yang dibuat tidak terdapat indikator keempat pada soal ini, diharapkan tidak lebih dari tiga level.

\section{Kemampuan Pemecahan Masalah Matematis Rendah (R)}

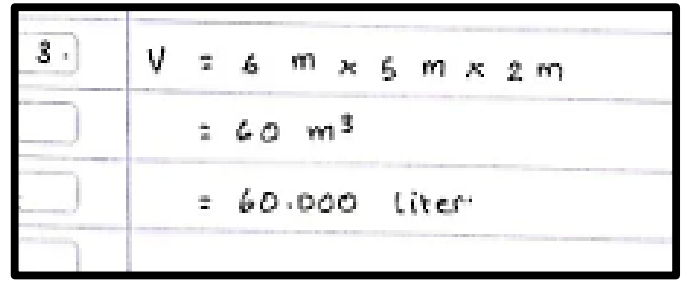

Gambar 4. Peserta Didik dengan Kemampuan Pemecahan Masalah Rendah.
Peserta didik dengan kemampuan pemecahan masalah matematis rendah, pada indikator pertama yaitu menunjukan permasalahan masalah, peserta didik dapat memahami kondisi atau masalah yang ada pada soal dan dapat memberikan informasi yang diketahui dan ditanyakan pada soal tersebut. Pada indikator ini salah satu peserta didik pada kategori (R) yaitu FT tidak menjawab apa yang ia ketahui dari soal, jadi tidak terdapat indikator pertama dalam jawaban soal. Pada indikator kedua yaitu membuat/menyusun model matematika, peserta didik dapat membuat suatu hubungan dari data yang diketahui dan tidak diketahui, pada indikator ini (FT) tidak membuat rumusan dari soal. Pada indikator ketiga yaitu memilih dan mengembangkan strategi pemecahan peserta didik dapat memilih dan mengembangkan strategi untuk melakukan perhitungan dengan segala macam yang dibutuhkan seperti konsep dan rumus yang sesuai, sesuai dengan apa yang telah dituliskan peserta didik di lembar jawabannya (lihat Gambar 4). Dan pada indikator keempat yaitu menjelaskan jawaban yang diperoleh dari penyelesaian masalah, peserta didik dapat berusaha untuk menjelaskan kembali jawaban dengan teliti setiap tahap yang dilakukan, tidak terdapat indikator keempat pada jawaban kedua peserta didik karena tidak menjelaskan kembali jawaban yang didapatkan sebelumnya.

Maka dari analisis yang telah dilakukan Pada indikator kemampuan pemecahan 
matematis yaitu menunjukkan permasalah matematis, pada indikator ini peserta didik diharapkan dapat memberikan informasi yang diketahui dan ditanyakan dari soal. Pada indikator ini peserta didik lebih dominan tidak menjawab apa yang diketahui dan ditanyakan dari soal. Menurut Roebyanto \& Harmini (2017:38) menunjukkan permasalahan masalah peserta didik harus tau dengan jelas permasalahnya jika ingin memecahkan masalah salah satu caranya dengan menentukan mana yang sudah diketahui dan mana yang belum diketahui.

Pada indikator kemampuan pemecahan matematis yaitu membuat atau membuat permodelan matematika, pada indikator ini dilakukan untuk mengetahui bagaimana peserta didik dapat merancang suatu hubungan dari data yang diketahui dan tidak diketahui. Pada indiaktor ini peserta didik mampu menjawab dengan benar tetapi belum tepat. Menurut Roebyanto \& Harmini (2017:41) cara untuk mengembangkan kemampuan peserta didik dalam pemecahan masalah adalah dengan penyediaan pengalaman pemecahan masalah ke masalah lainnya.

Pada indikator kemampuan pemecahan matematis yaitu memilih dan mengembangkan strategi pemecahan, pada indikator ini dilakukan untuk mengetahui bagaimana peserta didik dapat memilih dan mengembangkan strategi untuk melakukan perhitungan dengan segala macam yang dibutuhkan seperti konsep dan rumus yang sesuai. dimana pada indiaktor ini peserta didik mampu menjawab dengan benar tetapi belum tepat. Menurut Roebyanto \& Harmini (2017:44) strategi yang baik mengacu pada peserta didik yang menggunakan teknik/cara memecahkan masalah matematis dengan tepat sehingga membantu menentukan prosedur perhitungan untuk menemukan solusi.

Pada indikator kemampuan pemecahan matematis yaitu menjelaskan jawaban yang diperoleh dari penyelesaian masalah matematis, indikator ini dilakukan untuk mengetahui bagaimana peserta didik dapat berusaha untuk menjelaskan kembali jawaban dengan teliti setiap tahap yang dilakukan. Dimana pada indikator ini peserta didik belum mampu menjelaskan kembali jawaban yang mereka peroleh sebelumnya. Menurut Roebyanto \& Harmini (2017:47) setelah solusi ditemukan, peserta didik harus menerapkannya pada masalah untuk menjelaskan kembali jawaban yang didapatkan apakah kondisi masalah benar - benar ketemu.

\section{Penutup}

Berdasarkan hasil analisi data dan pembahasan, maka diperoleh kesimpulan persentase rata-rata kemampuan pemecahan masalah matematis peserta didik dari keempat indikator yang meliputi: menunjukan permasalahan masalah 38,35, membuat/menyusun model matematika 65,23, memilih dan mengembangkan strategi pemecahan 73,48, serta 
menjelaskan jawaban yang diperoleh dari penyelesaian masalah 31,54. Maka secara keseluruhan didapatkan persentase ratarata kemampuan pemecahan masalah matematis dikategorikan rendah sebesar 41,72 .

\section{DAfTAR PUStaka}

Afriansyah, E. A. (2013). Design Research: Place Value in Decimal Numbers Using Metric System. In International Seminar on Mathematics, Science, and Computer Science Education MSCEIS, Universitas Pendidikan Indonesia (UPI) Bandung.

Afriansyah, E. A. (2014). Addition and Substraction Numbers up to 10 through PMRI for SD/MI Level Students. International Postgraduate Colloqium of Research in Education 3rd IPCORE.

Afriansyah, E. A., Madio, S. S., Sumartini, T. S., Mardiani, D., Nurulhaq, C., Sritresna, T., \& Nuraeni, R. (2020). Jotform Application Training for Making Questionnaire and Attendance Forms. Jurnal Pekemas, 3(2), 26-32.

Albab, I. U., Saputro, B. A., \& Nursyahidah, F. (2017). Peningkatan kemampuan pemecahan masalah matematis mahasiswa melalui collaborative analysis of sample student responses. Mosharafa: Jurnal Pendidikan Matematika, 6(1), 35-44. Arimurti, I., Praja, E. S., \& Muhtarulloh, F. (2019). Desain Modul Berbasis Model
Discovery Learning untuk Kemampuan Pemahaman Matematis Siswa. Mosharafa: Jurnal Pendidikan Matematika, 8(3), 459-470.

Cahirati, P. E. P., Makur, A. P., \& Fedi, S. (2020). Analisis Kesulitan Belajar Siswa dalam Pembelajaran Matematika yang Menggunakan Pendekatan PMRI. Mosharafa: Jurnal Pendidikan Matematika, 9(2), 227-238.

Danim, S. (2017). Pengantar Kependidikan. Bandung: Alfabeta.

Febrilia, B. R. A. (2019). Penalaran Statistis Siswa dalam Menyelesaikan Masalah Case Study. Mosharafa: Jurnal Pendidikan Matematika, 8(2), 179190.

Firnanda, V., \& Pratama, F. W. (2020). Profil Kemampuan Pemecahan Masalah Matematika Pada Materi Segitiga Berdasarkan Teori Van Hielle. Mosharafa: Jurnal Pendidikan Matematika, 9(3), 487-498.

Hamzah, H. A., \& Muhlisrarini. (2014). Perencanaan dan Strategi Pembelajaran Matematika. Jakarta: PT RajaGrafindo Persada.

Herawati, L., \& Nurhayati, E. (2019). Eksperimentasi Model Pembelajaran Cooperative Script untuk Melatih Kecakapan Akademik Siswa. Mosharafa: Jurnal Pendidikan Matematika, 8(1), 131-142.

Latifah, S. S., \& Luritawaty, I. P. (2020). Think Pair Share sebagai Model Pembelajaran Kooperatif untuk Peningkatan Kemampuan Pemecahan 
Masalah Matematis. Mosharafa: Jurnal Pendidikan Matematika,9(1), 35-46.

Lestari, K. E., \& Yudhanegara, M. R. (2018). Penelitian Pendidikan Matematika. Bandung: PT Refika Aditama.

Lisnani, L. (2019). Pengaruh Penggunaan Konteks Daun terhadap Hasil Belajar Siswa. Mosharafa: Jurnal Pendidikan Matematika, 8(3), 423-434.

Mairing, J. P. (2018). Pemecahan Masalah Matematika. Bandung: Alfabeta.

Nurmawanti, I., \& Sulandra, I. M. (2020). Exploring of Student's Algebraic Thinking Process Through Pattern Generalization using Similarity or Proximity Perception. Mosharafa: Jurnal Pendidikan Matematika, 9(2), 191-202.

Rahman, A. A., \& Nasryah, C. E. (2020). Efektivitas Model Pembelajaran Missouri Mathematics Project untuk Meningkatkan Hasil Belajar Siswa SMA. Mosharafa: Jurnal Pendidikan Matematika, 9(2), 335-346.

Rinaldi, E., \& Afriansyah, E. A. (2019). Perbandingan

Kemampuan

Pemecahan Masalah Matematis Siswa antara Problem Centered Learning dan Problem Based Learning. NUMERICAL: Jurnal Matematika dan Pendidikan Matematika, 9-18.

Rokhima, N., \& Fitriyani, H. (2018). Student's Metacognition: Do Intrapersonal Intelligent Make Any Difference?. Mosharafa: Jurnal
Pendidikan Matematika, 7(2), 167178.

Sitohang, A. (2020). Analisis Kemampuan Pemecahan Masalah Matematik Pada Materi kubus dan Balok Berbentuk Soal Konteksual Ditinjau Dari Gender Siswa. Cartesius, 1-23.

Sopian, Y. A., \& Afriansyah, E. A. (2017). Kemampuan Proses Pemecahan Masalah Matematis Siswa melalui Model Pembelajaran Creative Problem Solving dan Resource Based Learning. Jurnal Elemen, 3(1), 97-107.

Sugiyono. (2018). Metode Penelitian Pendidikan (Pendekatan Kuantitatif, Kualitatif, dan R\&D. Bandung: Alfabeta.

Sumartini, T. S. (2016). Peningkatan Kemampuan Pemecahan Masalah Matematis Siswa Melalui Pembelajaran Berbasis Masalah. Mosharafa, 148-158.

Sumartini, T. S., Sunday, R., Madio, S. S., Afriansyah, E. A., Puspitasasri, N., Nuraeni, R., \& Lurytawati, I. P. (2020). Pedagogical Content Knowledge. Jurnal Pekemas, 3(1), 1012.

Widiawati, N., \& Sofyan, D. (2013). Perbandingan Prestasi Belajar Matematika Siswa antara yang Mendapatkan Metode Kumon dan Metode Konvensional. Mosharafa: Jurnal Pendidikan Matematika, 2(2), 99-110.

Yarmayani, A. (2016). Analisis Kemampuan Pemecahan Masalah Matematis Siswa 
Kelas XI Mipa Sma Negeri 1 Kota Jambi. Dikdaya, 12-19.

Zakiyah, S., Hidayat, W., \& Setiawan, W.

(2019). Analisis Kemampuan

Pemecahan Masalah dan Respon

Peralihan Matematik dari SMP ke SMA pada Materi SPLTV. Mosharafa: Jurnal

Pendidikan Matematika,8(2), 227238.

\section{Riwayat Hidup PENULIS}

\section{Hermawati, S.Pd.}

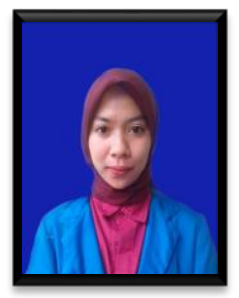

Lahir di Tebing, 10 Februari 1998. Studi S1 Pendidikan Matematika di Universitas PGRI Palembang, lulus pada Tahun 2021.

\section{Dra. Hj. Jumroh, M.Pd.}

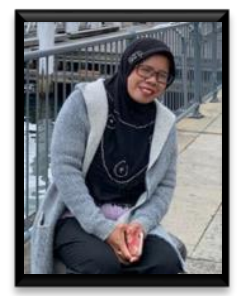

Staf pengajar di Universitas PGRI Palembang pada Program Studi Pendidikan Matematika. S1 Pendidikan Matematika di Universitas Muhammadiyah Palembang, lulus tahun 1989; S2 Pendidikan Matematika di Universitas Pendidikan Indonesia Bandung, lulus tahun 2003.

\section{Eka Fitri Puspa Sari, M.Pd.}

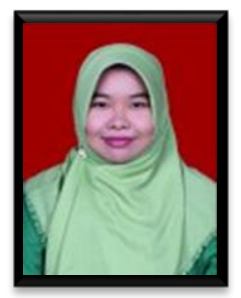

Staf pengajar di Universitas PGRI Palembang pada Program Studi Pendidikan Matematika. S1 Pendidikan Matematika di Universitas Sriwijaya Palembang, lulus tahun 2010; S2 Pendidikan Matematika di Universitas Sriwijaya Palembang, lulus tahun 2012. 